\title{
Estimation of Transpiration from a Single Maize Plant using a Dry Artificial Leaf
}

\author{
Hisashi KON, and Nobuhiro MATSUOKA \\ (Faculty of Horticulture, Chiba University, Matsudo 271-8510, Japan)
}

\begin{abstract}
Leaf transpiration of a potted maize plant was estimated, based on a heat balance model for a leaf, from the temperature difference between a dry artificial leaf and a real leaf. The temperature of the real leaf was measured in the sunlit horizontal part of the leaf on the upper position of the stem. The leaf transpiration estimated by the present method was in good agreement with that measured with a porometer for the same leaf. Transpiration from the whole maize plant was calculated by applying the leaf transpiration via the dry artificial leaf method to all the leaves of the plant, while the real plant transpiration was obtained by measuring the weight of the pot. Although the estimated plant transpiration differed from the real plant transpiration, the ratio of the real plant transpiration to the estimated plant transpiration for six days without water stress was almost constant at $0.54 \pm 0.02$. Taking the leaf position on the stem and the leaf curvature into consideration, this value seems to be appropriate. Thus, it seems possible to estimate the transpiration of a whole maize plant from the transpiration of a leaf by this ratio. For a maize plant under water stress, this ratio tended to be smaller than the value without water stress.
\end{abstract}

Key words: Artificial leaf, Leaf temperature, Maize, Transpiration.

\section{Introduction}

Estimating transpiration from plants is important in agricultural irrigation management and in the analysis of the earth's water cycle. Estimation methods include the porometer method, used to estimate transpiration from part of a leaf, and the stem heat budget method, used to measure transpiration from a single plant. Evapotranspiration from a uniform large plant canopy can be estimated by meteorological methods, for example, the Bowen ratio method and the eddy correlation method. Estimation of evapotranspiration using satellite observations has also been conducted (Shen et al., 2003).

No method to determine transpiration using leaf temperature has yet been established, although a direct relationship between leaf temperature and leaf transpiration has been confirmed (Haseba and Ito, 1975). Jones and Leinonen (2003) pointed out that leaf temperatures can be used to provide an indication of changes in transpiration rates, and used wet and dry

Received; March 22, 2007.

Accepted; April 3, 2008. leaves to examine plant water relations. In order to estimate transpiration by this method, the temperatures of the wet and dry leaves are needed. Paw $U$ and Daughtry (1984) used a leaf that was coated with a substance impervious to water as a dry leaf, while Qiu et al. (1996) used green paper as a dry artificial leaf to estimate transpiration in a sorghum field and Yamada et al. (2004) used coated leaves to estimate transpiration from a corn field. Recently, Yasutake et al. (2005) proposed a new method for evaluating the transpiration rate by applying abscisic acid (ABA) to a plant.

However, the relationship between the transpiration from a leaf and that from a single plant is not simple. Yu et al. (1996) used the average of many leaf transpiration measurements to obtain the transpiration rate of a single whole maize plant, while Kobayashi et al. (1993) described the need to multiply leaf transpiration by a certain correction factor in order to obtain the transpiration from a single plant. In order to estimate transpiration from a single plant or canopy from leaf transpiration measurements, further research is required. Little research into scaling up, from the 
estimation of leaf transpiration to single plant transpiration using an artificial leaf, has been done. Inoue et al. (1994) described that the leaf transpiration rate measured with a porometer on leaves near the top of a soybean canopy, is three to five times greater than the mean leaf transpiration rate, which is calculated from measurements of the sap flow rate and leaf area on a whole plant. However, since information concerning the relationship between leaf transpiration and whole plant transpiration is limited, further research based on fundamental experiments is required.

In this study, it was confirmed that evaporation from a wet artificial leaf was correctly estimated from the temperature difference between dry and wet artificial leaves of equivalent form. The real transpiration from a single potted maize plant was then compared with the transpiration estimated from the temperature differences between the dry artificial leaf and the real leaf.

\section{Method}

\subsection{Estimation of leaf transpiration}

Assuming that the heat storage in a leaf can be neglected, the temperatures of both sides of the leaf are the same and the sensible heat and latent heat fluxes at the surface are also the same for both sides of the leaf, the heat budget of the leaf can be expressed as follows:

$$
R=2 \sigma T^{4}+2 H+2 L E
$$

where $R$ is the radiation flux absorbed by both sides of the leaf $\left(\mathrm{W} \mathrm{m}^{-2}\right), T$ is the leaf temperature (in $\mathrm{K}$ ), $H$ is the sensible heat flux $\left(\mathrm{W} \mathrm{m}^{-2}\right), L$ is the heat of vaporization (in $\mathrm{J} \mathrm{kg}^{-1}$ ), $E$ is the transpiration rate $\left(\mathrm{kg} \mathrm{m}^{-2} \mathrm{~s}^{-1}\right)$ and $\sigma$ is the Stefan-Boltzmann constant $\left(5.67 \times 10^{-8} \mathrm{~W} \mathrm{~m}^{-2} \mathrm{~K}^{-4}\right)$. The emissivity of the leaf was approximated as 1 .

$R$ can be written as follows:

$$
R=(1+\alpha s) \lambda S+L a+L s
$$

where $\lambda$ is the absorption coefficient of shortwave radiation for the leaf, $\alpha s$ is the albedo of the ground under the leaf, $S$ is the global solar radiation $\left(\mathrm{W} \mathrm{m}^{-2}\right)$, and $L a$ and $L s$ are the long wave radiation $\left(\mathrm{W} \mathrm{m}^{-2}\right)$ intercepted by both surfaces of the leaf.

The dry artificial leaf temperature $(\mathrm{K})$, the leaf boundary layer resistance $\left(\mathrm{s} \mathrm{m}^{-1}\right)$ and the incident radiation $\left(\mathrm{W} \mathrm{m}^{-2}\right)$ are denoted by $T_{m}, r_{m}$ and $R_{m}$, respectively. For the real leaf, these are denoted by
$T_{f}, r_{f}$ and $R_{f}$. Hence, the heat budget equations of the two leaves are written as follows:

$$
\begin{aligned}
& R_{m}=2 \sigma T_{m}{ }^{4}+2 \rho c_{p}\left(T_{m}-T_{a}\right) / r_{m} \\
& R_{f}=2 \sigma T_{f}^{4}+2 \rho c_{p}\left(T_{f}-T_{a}\right) / r_{f}+2 L E
\end{aligned}
$$

where $\rho$ is the air density (in $\mathrm{kg} \mathrm{m}^{-3}$ ) and $c_{p}$ is the specific heat of air at constant pressure $\left(\mathrm{J} \mathrm{kg}^{-1} \mathrm{~K}^{-1}\right)$. Representing $r_{m}=n r_{f}$ and eliminating $r_{m}$ and $r_{f}$ from equations (3) and (4) gives:

$$
\begin{aligned}
L E= & R_{f} / 2-\sigma T_{f}^{4} \\
& -n\left(T_{f}-T_{a}\right)\left(R_{m}-2 \sigma T_{m}^{4}\right) /\left\{2\left(T_{m}-T_{a}\right)\right\}
\end{aligned}
$$

The transpiration rate $E$ can be calculated from this equation by assuming $n=1$.

As can be seen from equation (5), long and short wave radiation, air temperature, and the temperatures of the dry artificial leaf and the real leaf must be measured to use this model. Qiu et al. (2002) called this model the three-temperature model and used it to estimate the canopy transpiration.

\subsection{Measurement of transpiration}

\subsubsection{Measurement of evaporation from a wet artificial leaf}

Before conducting an experiment with a single maize plant, the present model was tested by using a wet artificial leaf of equivalent form to a dry artificial leaf.

Both the artificial leaves used for the experiment were made of circular aluminum disks $0.1 \mathrm{~mm}$ thick, with a diameter of $5 \mathrm{~cm}$. Gauze was placed on both surfaces of the disk and lusterless black paint was also applied to both surfaces so that the absorption coefficient of shortwave radiation for the artificial leaf could be regarded as one.

The leaf temperature was measured with a 0.1 mm Copper-Constantan thermocouple, which was fixed between the aluminum disk and the gauze. A wet artificial leaf was made by dipping a dry leaf in water and set horizontally at the same height as the dry artificial leaf. The weight of the wet leaf in the evaporation process was measured with an electronic platform scale (A\&D, EY-220A).

The wet artificial leaf experiment was initially conducted in a room, and subsequently outdoors, after confirming the correlation between the experimental and theoretical results. This paper describes the experi- 
ments performed outdoors. The output of the platform scale was disturbed by the wind, and hence only the readings obtained under stable output conditions were used in this analysis.

The details of the experimental procedure are the same as those described in 2.2.2, except for the scale used for weighing specimens.

\subsubsection{Measurement of transpiration from a single potted maize plant}

A single maize (Zea mays L.) plant in a pot was used to measure transpiration. During the experiment performed in 2004-2005, a cylinder type pot of diameter $15.8 \mathrm{~cm}$ and depth $19.2 \mathrm{~cm}$ was used, while in 2006 a larger pot of $25.2 \times 29.7 \mathrm{~cm}$ was used. Compost (Sakata Seed, SUPERMIX-A) was used for the soil in the pot. The experiments were conducted on fine days and the details of the experimental conditions are shown in Table 1. In 2004 and 2005, maize plants with six to nine leaves were used for the experiments. In 2006, they were at the flowering stage, and the head was cut off before experiments were conducted.

Sufficient water was applied to the pot on the morning of each day when an experiment was performed, except on 13 July, 2004 and 29 July and 2 August, 2005. After irrigation, the pot was covered with vinyl film to prevent soil surface evaporation. The plant used for the experiment on 13 July was irrigated on 8 July. After the pot was covered with vinyl film on 8 July, it was placed outdoors. The pot weighed $3955 \mathrm{~g}$ on 8 July and had decreased to $2778 \mathrm{~g}$ by the morning of 13 July.

During the experiments performed on 29 July and 2 August, 2005, the same specimen was used. It was irrigated on the morning of 27 July and the weight of the pot was $4296 \mathrm{~g}$ after irrigation. On the morning of 2 August, the weight had decreased to $2335 \mathrm{~g}$, suggesting that the plant was under high water stress. The degree of water stress was shown by (irrigated initial pot weight minus measured time pot weight) divided by the irrigated initial pot weight, here defined as the water stress index. The values are shown in Table 1. Time periods in which transpiration was measured are also shown in Table 1. The mean solar radiation and the mean air temperature are averages over the time periods. The mean air temperature for 1 October, 2004 was $25.9^{\circ} \mathrm{C}$, which was lower than on the other days.

The weighing of the pot was conducted with a load cell (MINEBEA, C2G1-6K) set on a desk, as shown in Fig. 1. The maize pot was placed on the load cell so that the leaves pointed east or west. The pot was also weighed with another platform scale $(A \& D$, EK-12KG) both before and after weighing with the load cell. As the experiment was conducted outdoors, the output of the load cell was disturbed by the wind. Readings that deviated significantly from the average were omitted from the data. After any correction, a 30-minute running mean was taken.

The temperature of a real leaf was measured with a $0.1-\mathrm{mm}$ thermocouple pasted on the back (abaxial side) of the sunlit horizontal part of the leaf at an upper position of the stem as shown in Fig. 1. The dry artificial leaf was set horizontally near the real leaf. The artificial leaf was the same as that described in the previous section and its temperature was measured with another thermocouple.

A long and short wave radiometer (EKO Seiki, MR40) was installed at the same height as the leaves and

Table 1. Experimental conditions.

\begin{tabular}{lcccccc}
\hline YMD & $\begin{array}{c}\text { Leaf } \\
\text { number }\end{array}$ & $\begin{array}{c}\text { Leaf } \\
\text { area }\left(\mathrm{m}^{2}\right)\end{array}$ & $\begin{array}{c}\text { Measurement time } \\
\text { period }(\mathrm{h}: \mathrm{m}-\mathrm{h}: \mathrm{m})\end{array}$ & $\begin{array}{c}\text { Mean solar } \\
\text { radiation }\left(\mathrm{W} \mathrm{m}^{-2}\right)\end{array}$ & $\begin{array}{c}\text { Mean air } \\
\text { temperature }\left({ }^{\circ} \mathrm{C}\right)\end{array}$ & Stress index** \\
\hline $04.7 .13^{*}$ & 7 & 0.152 & $9: 00-13: 00$ & 804 & 32.8 & 0.30 \\
04.7 .24 & 8 & 0.163 & $9: 35-15: 15$ & 823 & 33.2 & 0 \\
04.8 .19 & 8 & 0.158 & $9: 00-14: 27$ & 818 & 32.8 & 0 \\
04.9 .22 & 6 & 0.040 & $9: 00-15: 00$ & 684 & 30.8 & 0 \\
04.10 .1 & 7 & 0.084 & $9: 00-14: 30$ & 698 & 25.9 & 0 \\
$05.7 .29^{*}$ & 9 & 0.235 & $9: 00-15: 00$ & 734 & 30.7 & 0.21 \\
$05.8 .2^{*}$ & 9 & 0.245 & $9: 00-12: 30$ & 722 & 30.4 & 0.46 \\
05.8 .4 & 8 & 0.136 & $10: 10-12: 00$ & 877 & 33.0 & 0 \\
06.8 .3 & 9 & 0.473 & $9: 45-12: 27$ & 832 & 30.8 & 0 \\
\hline
\end{tabular}

YMD stands for Y: Year, M: Month, D: Day.

* indicates the day when the plant was under water stress conditions.

** stress index was calculated by

(irrigated pot weight-measured time pot weight)/irrigated pot weight 


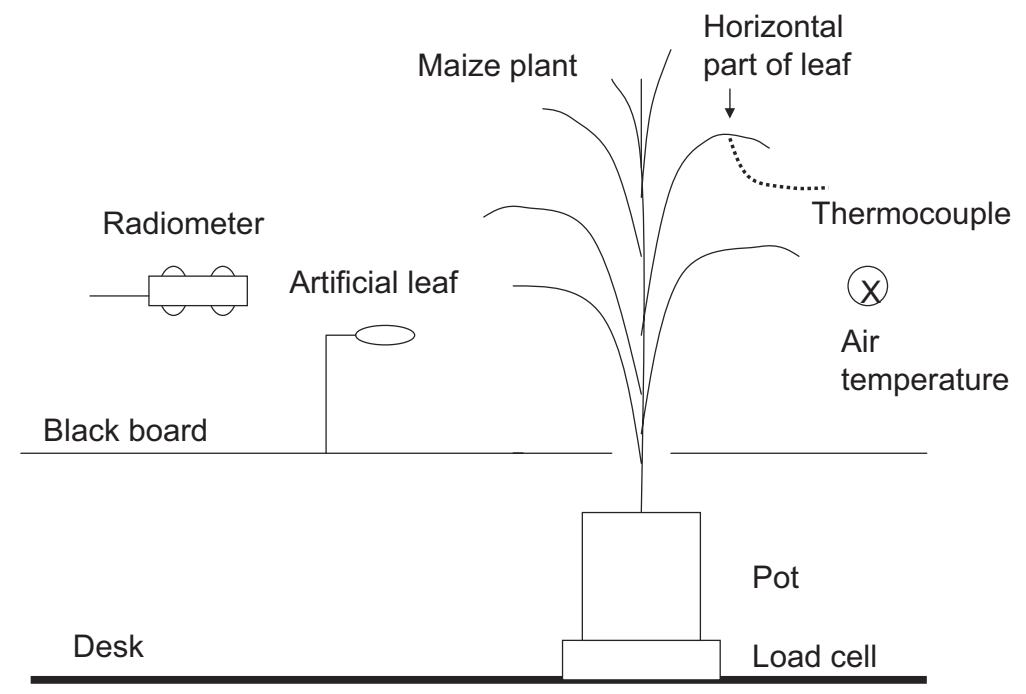

Fig. 1. Illustration of the experiment. The maize pot was put on a load cell set on a desk. The temperature of a real leaf was measured with a thermocouple that was pasted on the back of the horizontal part of the leaf. The dry artificial leaf and a long and short wave radiometer were set above a lusterless black board, which made the radiation coming from below uniform.

was used to measure the input radiation on both sides of the leaves. In order to make the radiation coming from below uniform, the desk was covered with a lusterless black board. Air temperature and wind were measured by an aspirated thermocouple psychrometer and a 2D ultrasonic wind sensor (EKO Seiki, MA-130). These were installed a few meters from the plant. The load cell records, leaf temperature and meteorological data were collected at intervals of one minute with a data logger (ETO Electricity, THERMODAC-E) and subsequently used for analysis.

The area of the maize leaf (A) used for the experiment was obtained by the following formula:

$$
\mathrm{A}=0.75 \mathrm{X} \times \mathrm{Y}
$$

where $\mathrm{X}$ and $\mathrm{Y}$ are the length and width of the leaf, respectively. This formula was proposed by Maddonni et al. (2001) and confirmed for the maize leaf used here (Liu, 2006).

Before this experiment was conducted, the optical properties of the maize leaf were measured. Firstly, a pyranometer was placed in an open-top box with the inside walls painted a lusterless black. The global solar radiation was measured in the open box. Subsequently, global solar radiation was measured in the box after it had been covered with maize leaves and the transmission coefficient $(0.20)$ was obtained from these measurements. Next, global solar radiation and reflected solar radiation were measured above the leaves, which were laid on a board painted lusterless black, and the reflection coefficient (0.30) of the leaf surface was obtained. The absorption coefficient of the maize leaf was 0.50 .

Based on the total leaf area of the plant and changes in the pot weight, the transpiration rate per unit leaf area $\left(\mathrm{kg} \mathrm{m}^{-2} \mathrm{~s}^{-1}\right)$ was calculated and compared with the transpiration value obtained from equation (5).

\subsubsection{Measurement of transpiration with a porom- eter}

Leaf transpiration obtained by the dry artificial leaf method was compared with the measurement obtained using a porometer (LI-COR, LI-1600). The porometer measurement was performed on the adaxial and abaxial surfaces near the temperature measurement point for the same leaf, and the average was used for comparison with the measurement based on the dry artificial leaf method.

\section{Results and Discussion}

\subsection{Evaporation from a wet artificial leaf}

The measured and estimated evaporation from a wet artificial leaf on 26 April, 2004 are shown in Fig. 2. The solid lines depict the estimate made every minute and the crosses are the individual measurements. A 


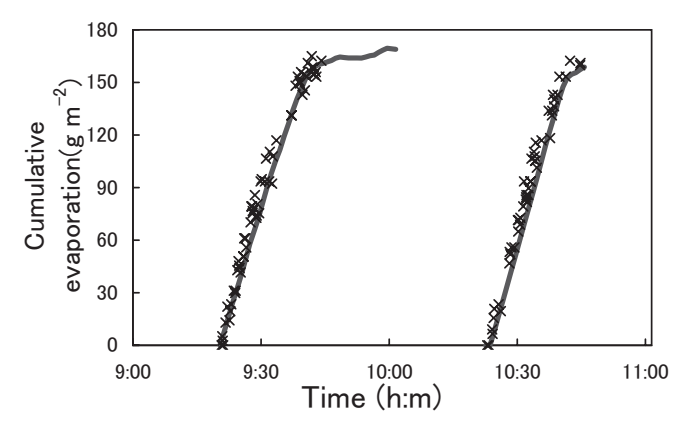

Fig. 2. Comparison of cumulative evaporation between the measured (cross) and the estimated (solid line) values. The estimated value was obtained by the model on 26 April 2004 using a dry artificial leaf and a wet artificial leaf of the same form. The two lines with crosses show the two runs.

measurement was made, however, only when the output of the scale was stable. This experiment was performed twice in succession, as shown in Fig. 2.

The evaporation rate from the wet artificial leaf was almost fixed when the leaf surface remained wet, but decreased suddenly when the surface dried (Fig. 2). The difference between the measured and estimated cumulative evaporation at the time when evaporation had almost ceased was smaller than $10 \mathrm{~g} \mathrm{~m}^{-2}$. This value was about $5 \%$ of the total evaporation of about $160 \mathrm{~g} \mathrm{~m}^{-2}$, which shows that the estimation is reliable.

3.2. Example of measurement of transpiration from a single potted maize plant

\subsubsection{Measurement of transpiration with a load cell}

Example measurement of the maize pot weight using a load cell is shown in Fig. 3. The measurement was conducted on 24 July, 2004. The thin solid line shows the raw data. Since the output was disturbed by the wind, the line shows saw-toothed fluctuations.

The thick solid line shows the 30-minute running mean. This mean weight was used for the following analyses.

\subsubsection{Time variations in meteorological ele- ments}

The time variations in meteorological elements on 24 July are shown in Fig. 4. The weather was fine, although there were a few clouds in the sky in the morning. Because a long and short wave radiometer was installed over a black board, the reflective solar radiation was smaller and the upward long wave

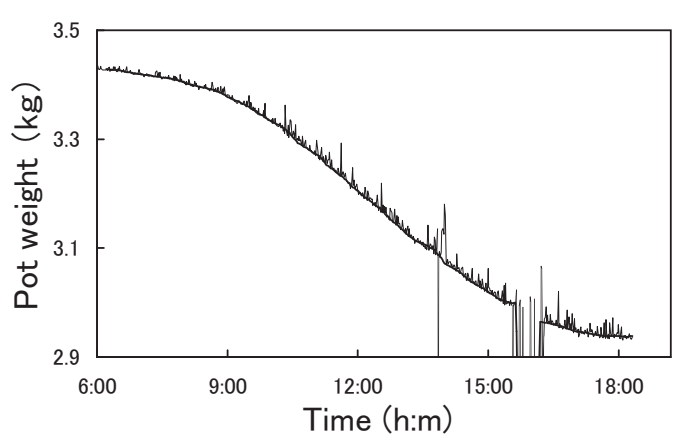

Fig. 3. Time variations in the weight of a maize pot measured on 24 July 2004 each minute. Measurement obtained with a load cell (-) and the 30-minute running mean $(-)$.

radiation was larger than generally expected over the ground surface.

The wind speed shown in Fig. 4b was low during the morning but increased in the afternoon. The air and artificial leaf temperatures are shown in Fig. 4c. The temperature of the dry, black artificial leaf was around $50^{\circ} \mathrm{C}$ and the temperature difference between the artificial leaf and the air was around $20^{\circ} \mathrm{C}$ at midday. Leaf temperatures were measured for the 5 th leaf from the top pointing eastward and for the 6th leaf pointing westward. The temperature of the two leaves differed by about $-1 \sim 3^{\circ} \mathrm{C}$ from the air, as shown in Fig. $4 \mathrm{~d}$.

\subsubsection{Estimation of transpiration}

The heat fluxes at the leaf pointing eastward are shown in Fig. 5a. The thin solid line represents the sum of the 1st and 2nd terms on the right-hand side of equation (5). The thick solid line shows the $3 \mathrm{rd}$ term of the right-hand side of the equation and the dashed line expresses $L E$. Since the leaf-air temperature difference was slight, the sensible heat flux was small and the latent heat flux was nearly equal to the net absorbed radiation.

The transpiration rate estimated from the leaf heat balance and the transpiration rate measured with the load cell are shown in Fig. 5b. The transpiration rates estimated from the leaf pointing eastward and the leaf pointing westward were almost the same, roughly 5 6 $\mathrm{g} \mathrm{m}^{-2} \mathrm{~min}^{-1}$ in this experiment. However, although the fluctuation in the transpiration rate obtained by weighing the maize pot was considerable, the average rate was roughly $3 \mathrm{~g} \mathrm{~m}^{-2} \mathrm{~min}^{-1}$. The measured value was about half of the estimates made by the artificial leaf method. 

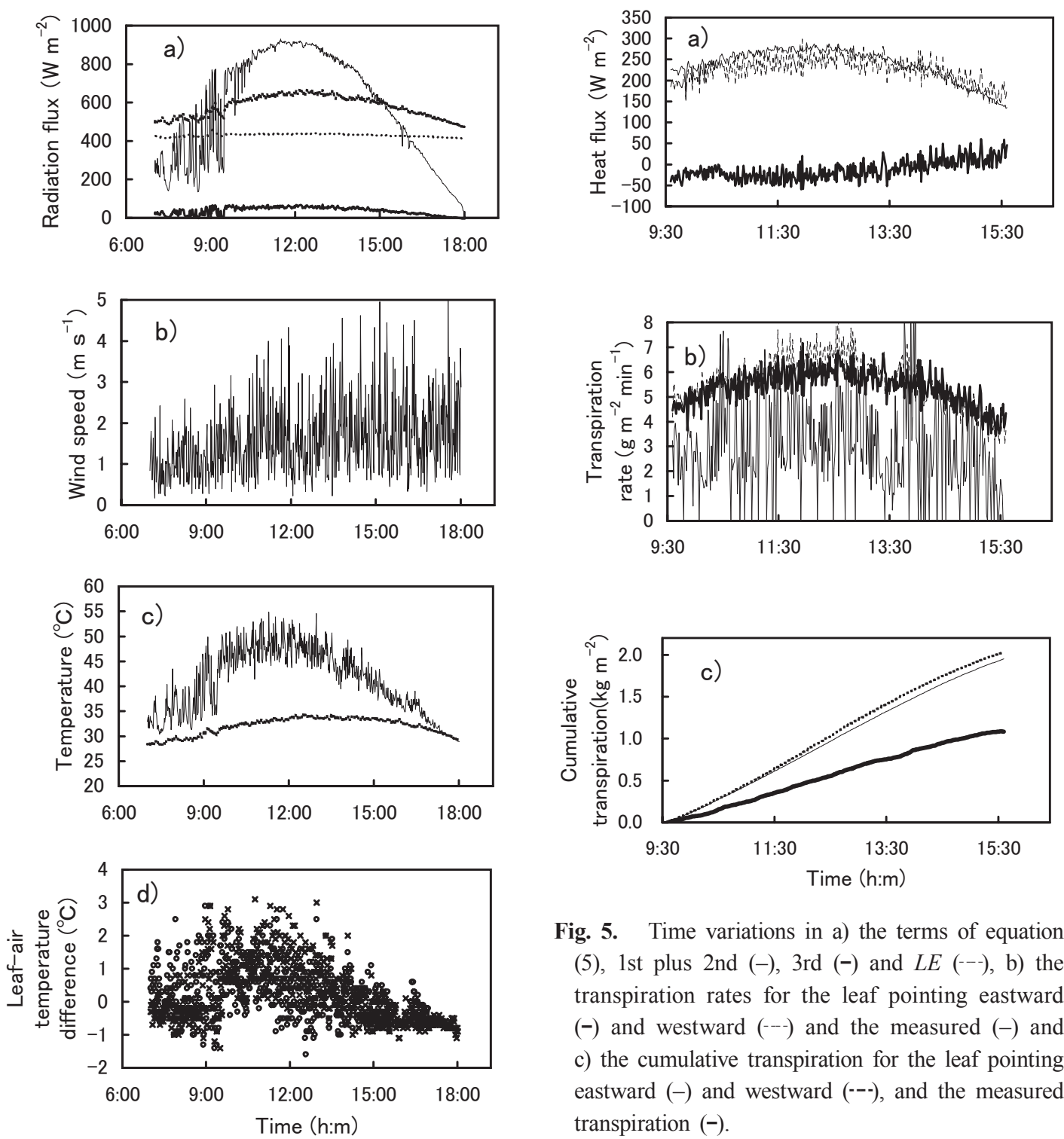

Fig. 5. Time variations in a) the terms of equation (5), 1st plus 2nd (-), 3rd (-) and LE (--), b) the transpiration rates for the leaf pointing eastward $(-)$ and westward (--) and the measured (-) and c) the cumulative transpiration for the leaf pointing eastward (-) and westward (---), and the measured transpiration (-).

Fig. 4. Time variations in a) solar radiation (-), reflective solar radiation (-), atmospheric radiation $(\ldots)$, and upward long wave radiation $(--)$, b) wind speed, c) air temperature (-) and dry artificial leaf temperature $(-), d)$ leaf-air temperature differences of the leaf pointing eastward $(\times)$ and westward

The cumulative transpiration from the single maize plant, as measured with the load cell and estimated by the model, are shown in Fig. 5c. The ratios of the measured value to the estimated value during the time period were 0.55 for the westward facing leaf and 0.57 for the eastward-facing leaf respectively.

The reasons why the actual transpiration from the maize plant appeared smaller than the estimated transpiration:

1) Leaves at a higher position of the stem transpire more than those in a lower position (Yu et al., 1996).

2) Some leaves in a lower position are apt to be in the shade.

3) Transpiration from the inclined part of a leaf is generally small because of small incident solar radiation. 


\subsection{Comparison between the porometer and the dry artificial leaf method}

The estimates of transpiration made every minute by the artificial leaf model and the measurements made with the porometer on 22 September, 2004 are shown in Fig. 6. Measurements with the porometer for the two leaves, pointing eastward and westward, were made almost simultaneously, and were in good agreement with the result of the dry artificial leaf method. The fluctuation in the transpiration estimates seems to show the sensitivity of transpiration to weather conditions. Since the dry artificial leaf method is capable of measuring transpiration continuously without disturbing the state of the leaf, this method seems more effective than the porometer method for a sunlit horizontal leaf in fine weather conditions.

In equation (5), $n=1$ was assumed. Based on the results of the comparison with the porometer, this assumption appears reasonable.

\subsection{Summary of measurements for nine days}

Results are summarized in Table 2 for the nine days when the experiment was conducted. For the six runs without water stress, the average ratio of the measured to estimated transpiration was $0.54 \pm 0.02$, with low standard deviation. Thus, it seems possible to estimate the transpiration of a single maize plant from that of a leaf using this ratio.

Because of the low air temperature, the transpiration rate on 1 October, 2004 was smaller than on other days. However the ratio was within the range of the standard deviation (i.e. $0.54 \pm 0.02$ ). In the case of 3
August, 2006, the maize plant was in its heading stage and the transpiration rate $\left(0.14 \mathrm{~kg} \mathrm{~m}^{-2} \mathrm{hr}^{-1}\right)$ was smaller than in the younger stages. The leaf-air temperature differences were $3-5^{\circ} \mathrm{C}$ at midday, but the ratio was almost equal to the average. These results show that the effect of the growth stage on the measured to estimated transpiration ratio is relatively small.

The ratio of the measured to the estimated transpiration was 0.49 in the experiment conducted on 13 July, which was a smaller value observed than in the other experiments in 2004. On 24 July and 19 August, solar radiation was comparable to that of 13 July, as shown in Table 1. Although the leaf-air temperature difference was around $1^{\circ} \mathrm{C}$ in most of the experiments, it was $5-7^{\circ} \mathrm{C}$ in that conducted on 13 July because of water stress. The influence of water stress on transpiration

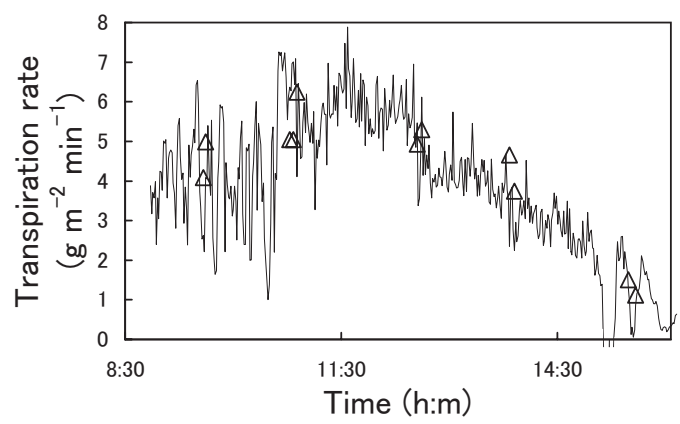

Fig. 6. Comparison of the transpiration rates from maize leaves measured with a porometer $(\triangle)$ and the dry artificial leaf method (-) on 22 September 2004.

Table 2. Comparison between the estimated and the measured transpiration in each run. Leaf position was numbered from the top of stem.

\begin{tabular}{|c|c|c|c|c|c|c|}
\hline \multirow[b]{2}{*}{ YMD } & \multirow[b]{2}{*}{$\begin{array}{c}\text { Leaf } \\
\text { position }\end{array}$} & \multicolumn{2}{|c|}{ Cumulative transpiration } & \multicolumn{2}{|c|}{ Transpiration rate } & \multirow[b]{2}{*}{$\begin{array}{c}\text { Ratio of measured } \\
\text { to estimated }\end{array}$} \\
\hline & & $\begin{array}{c}\text { Measured } \\
\left(\mathrm{kg} \mathrm{m}^{-2}\right)\end{array}$ & $\begin{array}{l}\text { Estimated } \\
\left(\mathrm{kg} \mathrm{m}^{-2}\right)\end{array}$ & $\begin{array}{c}\text { Measured } \\
\left(\mathrm{kg} \mathrm{m}^{-2} \mathrm{hr}^{-1}\right)\end{array}$ & $\begin{array}{c}\text { Estimated } \\
\left(\mathrm{kg} \mathrm{m}^{-2} \mathrm{hr}^{-1}\right)\end{array}$ & \\
\hline 04.7 .13 & 3 & 0.60 & 1.23 & 0.15 & 0.31 & $0.49 *$ \\
\hline 04.7 .24 & 5 & 1.06 & 1.90 & 0.20 & 0.34 & 0.56 \\
\hline 04.8 .19 & 3 & 1.07 & 2.04 & 0.20 & 0.37 & 0.52 \\
\hline 04.9 .22 & 3 & 0.89 & 1.60 & 0.15 & 0.27 & 0.56 \\
\hline 04.10 .1 & 3 & 0.67 & 1.29 & 0.12 & 0.23 & 0.52 \\
\hline 05.7 .29 & 5 & 0.55 & 1.23 & 0.092 & 0.21 & $0.44^{*}$ \\
\hline 05.8 .2 & 4 & 0.085 & 0.37 & 0.024 & 0.11 & $0.23^{*}$ \\
\hline 05.8 .4 & 3 & 0.36 & 0.71 & 0.20 & 0.39 & 0.51 \\
\hline 06.8 .3 & 2 & 0.39 & 0.74 & 0.14 & 0.27 & $0.53 \#$ \\
\hline
\end{tabular}

YMD stands for Y: Year, M: Month, D: Day.

* indicates the day when the plant was under water stress.

\# indicates the experiment in which the larger pot was used. 
was reexamined on 29 July and 2 August, 2005. Water stress was extremely severe on 2 August; the average leaf-air temperature difference during the period was $5.3^{\circ} \mathrm{C}$, meaning the ratio of the measured to estimated transpiration was 0.23 . If the transpiration from the leaves at lower positions of the stem is more strongly influenced by water stress than those at upper positions, the smaller ratio can be explained.

The ratio of measured to model-estimated transpiration may depend on plant species. Further investigations are required to clarify whether the ratio is related to plant species.

\section{Summary}

Leaf transpiration can be estimated from the temperature difference between a dry leaf and a real leaf by the leaf heat balance model; based on the assumption of equivalent boundary layer resistances for both leaf surfaces.

Before a real plant experiment, evaporation from a wet artificial leaf was estimated using another dry artificial leaf of equivalent form to confirm the model suitability. The result showed that evaporation could be predicted by the model.

The leaf transpiration of a potted maize plant was then estimated based on the model. The temperature of the real leaf was measured in the sunlit horizontal part of the leaf on the upper position of the stem. The leaf transpiration estimated by the model was in good agreement with that measured using a porometer for the same leaf. Transpiration from the whole maize plant was calculated by applying the leaf transpiration by the dry artificial leaf method to all the leaves of the plant. Real plant transpiration was obtained by measuring the weight of the pot. The estimated plant transpiration differed from the real plant transpiration. However, the ratio of the real plant transpiration to the estimated plant transpiration for six days without water stress was a virtually constant value: $0.54 \pm 0.02$. Taking the leaf position on the stem and the leaf curvature into consideration, this value seems reasonable. Thus, it seems possible to estimate the transpiration of a whole maize plant from the transpiration of a leaf using this ratio.

For three days under water stress, this ratio tended to be smaller than the ratio without water stress. If the transpiration from the leaves at the lower positions of the stem were more strongly influenced by water stress than those in the upper positions, this would explain the smaller value of the ratio.

It is necessary to confirm whether this method can be effective under various conditions with various plants.

\section{References}

Haseba, T., and Ito, D., 1975: Studies of transpiration in relation to the environment (7). Variation of transpiration rate and leaf temperature with meteorological elements. J. Agric. Meteorol., 30, 173-182.

Inoue, Y., Sakuratani, T., Shibayama, M., and Morinaga, S., 1994: Remote and real-time sensing of canopy transpiration and conductance-comparison of remote and stem flow gauge methods in soybean canopies as affected by soil water status-. Jpn. J. Crop Sci. 63, 664-670.

Jones, H. G., and Leinonen, I., 2003: Thermal imaging for the study of plant water relations. J. Agric. Meteorol., 59, 205-217.

Kobayashi, T., Yoshikawa, K., Kobashi, S., and Masuda, T., 1993: Comparative analysis of water dynamics of Salix matsudana growing under different soil moisture conditions. J. Jpn. For. Soc., 75, 165-175.

Liu, L., 2006: Stomatal conductance, transpiration and hydraulic properties in field grown maize (Zea mays L.). Docter thesis, Chiba Univ. Japan, 107 pp.

Maddonni, G. A., Otegui, M. E., and Cirilo, A. G., 2001: Plant population density, row spacing and hybrid effects on maize canopy architecture and light attenuation. Field Crops Research, 71, 183-193.

Paw U, K. T., and Daughtry, C. S. T., 1984: A new method for the estimation of diffusive resistance of leaves. Agric. Forest Meteorol., 33, 141-155.

Qiu, G. Y., Momii, K., and Yano, T., 1996: Estimation of plant transpiration by imitation leaf temperature -Theoretical consideration and field verification(I) -. Trans. Jpn. Soc. Irrig. Drain. Reclam. Eng., 64, 401-410.

Qiu, G. Y., Miyamoto, K., Sase, S., Gao, Y., Shi, P., and Yano, T., 2002: Comparison of the three-temperature model and conventional models for estimating transpiration. JARQ, 36, 73-82.

Shen, Y., Zhang, Y., Kondoh, A., Tang, C., and Sakura, Y., 2003: Estimating regional evapotranspiration using Landsat remote sensing data. Proceeding of JAHS, 18, 62-65.

Yamada, T., Akiba, N., Yano, T., and Kitamura, Y., 2004: Estimation of crop transpiration from a corn field with leaf temperature measurements. J. Arid 
Land Studies, 14, 17-26.

Yasutake, D., Kitano, M., Hidaka, K., He,W., and Kobayashi, T., 2005: A method for in situ evaluation of transpirational water loss from crop field by applying abscisic acid to plants. J. Agric. Meteorol.,
60, 1117-1120.

Yu, G-R., Nakayama, K., and Matsumura,H., 1996: Comparison on variability of stomatal conductance between adaxial and abaxial surfaces of maize leaf. J. Agric. Meteorol., 52, 141-148.

\section{乾燥模擬葉を使ったトウモロコシ個体蒸散量の算定}

今 久. 松岡延浩

(千葉大学園芸学部)

要

ポットに植えられたトウモロコシ葉の蒸散が, 葉の熱収 支モデルに基づき乾燥模擬葉と実葉の温度差から算定さ れた。実葉の温度は茎の上部にある葉の日当たりが良い 水平部分で測定された。このモデルで算定された葉蒸散 量は同じ葉についてポロメータで測定された值と良く一致 した。得られた葉蒸散量を個体全部の葉に当てはめるこ とで, トウモロコシ個体全体からの蒸散量が算定された。 この算定個体蒸散量は実際の個体蒸散量とは異なるもの である。実際の個体蒸散量はポットの重量を測定するこ
約

とで求めた。水ストレスがない 6 日間について算定個体 蒸散量に対する実個体蒸散量の比は, ほとんど一定で, $0.54 \pm 0.02$ になった。茎についている葉の位置や葉の 曲がりを考えると, この值は妥当であると考えられる。こ の比を使うことによって葉の蒸散量からトウモロコシ個体 全体の蒸散量を算定できる。水ストレスがあるトウモロコ シについて, この比は小さくなる傾向にあった。 キーワード : 模擬葉, 葉温, トウモロコシ, 蒸散 